Reymon Suri Putra, M. Fachri Adnan| Strategi Pemerintah Kota Padang dalam Pengembangan Pantai Muaro Lasak Sebagai Ikon Parawisata

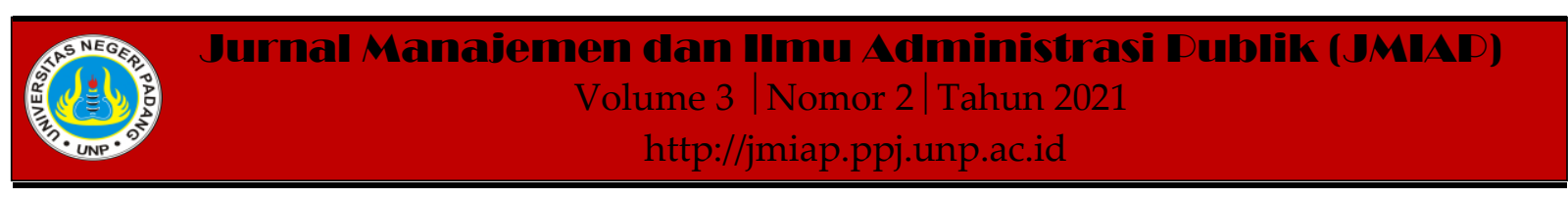

\title{
STRATEGI PEMERINTAH KOTA PADANG DALAM PENGEMBANGAN PANTAI MUARO LASAK SEBAGAI IKON PARAWISATA
}

\author{
Reymon Suri Putra ${ }^{1(a)}$, M. Fachri Adnan ${ }^{2(b)}$ \\ ${ }^{1}$ Jurusan Ilmu Administrasi Negara, Universitas Negeri Padang \\ ${ }^{2}$ Jurusan Ilmu Administrasi Negara, Universitas Negeri Padang \\ ${ }^{a)}$ reymonsuriputra07@gmail.com, ${ }^{b}$ fachri.adnan@gmail.com
}

\begin{abstract}
This research aimed to analyze the strategy of Padang City Government in developing the Muaro Lasak beach as tourism icons. This was a qualitative research with descriptive qualitative method. Informants of this research were determined with purposive sampling, that was Tourism and Culture Department of Padang City, Public Works and Public Housing Services of Padang City, the tourists, traders, and parking attendants on the Muaro Lasak beach. This research used primary and secondary data derived from observation, interview, and documentation study. Validity tested of this data used source triangulation technique, and than the data were analyzed with qualitative data technique. The results of the research showed that neeed increased supervision, security and development in the strategy of Padang City Government in developing the Muaro Lasak beach as tourism icons. In addition, there are supporting factors and inhibiting factors in this case.

Keywords : Strategy, Developing, Tourism Icons

Corresponding author. Email. reymonsuriputra07@gmail.com

How to cite this article. Putra, R. Suri \& Adnan, M. Fachri. (2021). Strategi Pemerintah Kota Padang dalam Pengembangan Pantai Muaro Lasak Sebagai Ikon Parawisata. Jurnal Manajemen dan Ilmu Administrasi Publik (JMIAP) Jurusan Ilmu Administrasi Negara Fakultas Ilmu Sosial Universitas Negeri Padang, Volume 3 (2), Hal. 126-134.

http://jmiap.ppj.unp.ac.id

Copyright $\odot 2021$. Published by Labor Jurusan Ilmu Administrasi Negara FIS UNP, Padang
\end{abstract}




\section{PENDAHULUAN}

Sumatera Barat adalah salah satu provinsi di Indonesia yang sedang gencar memaksimalkan sektor pariwisatanya. Hal ini didasarkan oleh munculnya kesadaran Pemerintah daerah akan pentingnya peran sektor pariwisata dalam mendorong perekonomian rakyat. Sumatera Barat memang cukup dikenal sebagai daerah yang memiliki berbagai tempat wisata yang indah. Hampir di setiap daerah di Sumatera Barat, memiliki tempat wisata alam yang sangat diminati oleh para wisatawan, tidak terkecuali Ibukota Provinsi Sumatera Barat, Kota Padang, yang memiliki cukup banyak daerah parawisata.

Menurut data sumber Badan Pusat Statistik Kota Padang, tahun 2018 Kota Padang memiliki jumlah objek wisata yang cukup banyak terdiri dari, wisata kuliner, wisata belanja, wisata budaya, wisata sejarah, wisata bahari dan wisata alam yang tersebar di beberapa kecamatan di Kota Padang.

Pemerintah Kota Padang khususnya Dinas Parawisata dan Kebudayaan saat ini telah melakukan beberapa pengembangan di kawasan Pantai Padang Kota Padang pada khusunya di kawasan Pantai Muaro Lasak pemerintah Kota Padang juga melakukan beberapa pembangunan untuk menunjang fasilitas - fasilitas untuk para pengunjung wisatawan domestik maupun mancanegara diantaranya adalah berupa fasilitas untuk pejalan kaki Trotoar untuk para pengunjung wisata ingin meikmati keindahan Pantai Muaro Lasak, fasilitas penunjang seperti tugu merpati untuk mempercantik atau menjadikan ikon untuk kawasan Pantai Muaro Lasak.

Selain itu pengembangan pantai Muaro Lasak ini dilakukan guna menjalankan dan mengimplementasikan Undang - Undang No 10 Tahun 2009 tentang Keparawisataan dan menjalankan RPJMD Kota Padang 2014-2019 misi ke tiga Walikota Padang "menjadikan Kota Padang Sebagai Daerah Tujuan Wisata yang nyaman dan berkesan" dengan program unggulan merevitalisasi objek wisata Kota Padang menjadi wisata keluarga dan konvensi yang layak dan ramah.

Fasilitas lainnya yang telah disediakan oleh pemerintah Kota Padang di kawasan Pantai Muaro Lasak berupa lampu penerangan di sekitar Trotoar, Pos pengamanan untuk keamanan pengunjung dan berupa tempat parkir yang di tempatkan di bibir jalan kawasan Pantai Muaro Lasak tersebut. Namun walaupun banyaknya fasilitas-fasilitas dan pengunjung yang berkunjung ke Kota Padang bukan berarti tidak adanya masalah yang terdapat pada Parawisata Kota Padang tersebut.

Pada salah satu Parawisata di Kota Padang yaitu Pantai Muaro Lasak menjadi salah satu daya tarik para wisatawan untuk berkunjung kesana terdapat beberapa masalah terkait dengan daerah Parawisata Kota Padang diantaranya yaitu kurangnya lahan parkir didaerah Parawisata Kota Padang yakni di Pantai Muaro Lasak yang membuat kurangnya minat para wisatawan berkunjung ke sana karena mereka hanya parkir di sepanjang jalan tersebut. Kemudian, kebersihan yang kurang baik di kawasan Pantai Muaro Lasak khususnya pada bibir Pantai yang jika dilihat banyaknya sampah-sampah seperi plastik maupun sampah bekas makanan lainya apa lagi ketika sudah memasuki musim hujan sampah-sampah jadi menumpuk ketika selesai hujan datang.

Hal ini membuat keindahan Pantai Muaro Lasak menjadi kurang bagus. Masalah lainnya yaitu kurang selarasnya dalam RPJMD Kota Padang 2014-2019 misi ke tiga Walikota Padang "menjadikan Kota Padang Sebagai Daerah Tujuan Wisata yang nyaman dan berkesan" dengan program unggulan merevitalisasi objek wisata Kota Padang menjadi wisata keluarga dan konvensi yang layak dan ramah.

Berdasarkan latar belakang masalah diatas, penulis rumuskan permasalahan sebagai berikut : Pertama, bagaimana Upaya Pemerintah dalam Pengembangan Pantai Muaro Lasak sebagai salah satu Ikon Parawisata Kota Padang; Kedua, Faktor- 
faktor yang mempengaruhi Pengembangan Pantai Muaro Lasak sebagai Ikon Parawisata Kota Padang.

\section{TINJAUAN PUSTAKA}

\section{Strategi Pengembangan Parawisata}

Menurut bapak Suryono (2004:80) strategi pada prinsipnya adalah hal berkaitan dengan persoalan antara lain: kebijakan dalam pelaksanaan, penentuan dari tujuan yang hendak kita dicapai, dan penentuan dari cara-cara atau metode dari penggunaan sarana-prasarana. Strategi selalu berkaitan dengan 3 hal yaitu tujuan, sarana, dan cara. Oleh karena hal itu, strategi juga harus didukung kemampuan untuk mengantisipasi dari kesempatan yang ada. Dalam pelaksanakan fungsi dan peranannya dalam pengembangan pariwisata daerah, pemerintah daerah harusnya melakukan berbagai upaya dalam pengembangan sarana dan prasarana pariwisata.

Salah satu teori pengembangan pariwisata yaitu teori yang dikemukakan oleh Yoeti (1997:2), bahwa perencanaan dan pengembangan pariwisata perlu memperhatikan beberapa aspek, yang perlu diperhatikan yaitu:

1. Wisatawan (tourist), perlunya mengetahui bagaimana karakteristik dari wisatawan yang akan berkunjung, dari negara mana mereka datang,berapa usia, hobi, dan pada musim apa saja mereka melakukan perjalanan wisata ke tempat tertentu.

2. Fasilitas Transportasi, dalam pengembangan parawisata harus dilakukan penelitian bagaimana fasilitas transportasi yang tersedia untuk membawa wisatawan ke daerah tujuan wisata yang dituju sehingga memudahkan mereka berpindah ke tempat wisata satu ke tempat wisata lainnya.

3. Objek wisata, objek wisata yang akan dijual dan dituju, apakah memenuhi tiga syaratseperti: a) apa yang dapat dilihat bagaimana tempat yang tersedia sehingga menarik minat mereka melihat tempat tersebut (something to see), b) apa yang dapat dilakukan, apa saja yang dapat dilakukan di tempat wisata tersebut harus tersedianya tempattempat rekreasi sehingga para wisatawan tidak merasa bosan berkunjung kesana (something to do), c) apa yang dapat dibeli, apa yang dapat dibeli harus tersedianya fasilitas tempat makanan di tempat parawisata tersebut (something to buy).

4. Fasilitas pelayanan, fasilitas apa saja yang tersedia di DTW tersebut, bagaimana akomodasi perhotelan yang ada, restaurant, pelayanan umum seperti bank, kantor pos, telepon, yang ada di DTW tersebut.

5. Informasi dan promosi, diperlukan publikasi atau promosi, kapan iklan dipasang, kemana brosur disebarkan sehingga calon wisatawan mengetahui tiap paket wisata dan wisatawan cepat mengambil keputusan pariwisata di wilayahnya dan harus menjalankan kebijakan yang paling menguntungkan bagi daerah dan wilayahnya.

Kemudian, peranan pemerintah dalam pengembangan parawisata menurut Achmad Afandi (2017), Pemerintah merupakan salah satu stakeholder di dalam pengelolaan bidang pariwisata. Pemerintah juga memimliki fungsi sebagai pembuat berbagai kebijakan tentang pariwisata pada suatu daerah serta berperan dalam meningkatkan devisa dan pendapatan asli daerah melalui bidang pariwisata. Pemerintah daerah dalam hal ini Disbudparpora yang menaungi bidang kepariwisataan diharapkan memiliki peran dalam menyediakan pariwisata di daerahnya dengan cara mengembangkan daya tarik serta saran kepariwisataan lainnya. Hal tersebut akan mampu terwujud jika pemerintah selaku pemegang kepentingan mampu mengembangkan pariwisata secara optimal.

Lalu kemudian ada konsep analisis SWOT (Salusu,2015:175), yang memperkenalkan konsep tersebut untuk mengetahi dari Strengths (kekuatan), 
Weaknesses (kelemahan), Opurtunities (Peluang) dan Threats (Ancaman). Ke empat faktor tersebut terbagi menjadi dua faktor utama yaitu : Faktor internal dan Faktor eksternal.

Faktor internal meliputi dari kekuatan dan kelemahan.

\section{Strengths (Kekuatan)}

Kekuatan merupakan situasi dan kemampuan internal yang bersifat positif yang memungkinkan organisasi memiliki keuntungan stratejik dalam mencapai sasarannya.

Apabila kekuatan cukup berarti maka dapat dimanfaatkan untuk memperbaiki kelemahan. Sebaliknya jika kelemahan dominan maka dapat mengubah kekuatan menjadi kelemahan.

Kekuatan hendaknya digunakan untuk mengubah kelemahan menjadi kekuatan. Beberapa elemen penting yang dipandang sebagai kekuatan seperti : lokasi yang strategis, keamanan yang terjamin, dukungan DPR/DPRD, visi dan misi yang mampu mendarat dalam hati masyarakat sumber daya manusia yang berkualitas, dan sebagainya.

2. Kelemahan (Weaknesess)

Pada dasarnya merupakan kekurangan atau kelemahan yang dimiliki oleh suatu daerah atau organisasi tertentu dibandingkan dengan organisasi lainnya. Kelemahan suatu organisasi tidak boleh dibiarkan sepanjang perbaikan dapat dilakukan.

Kelemahan suatu organisasi tidak boleh dibiarkan sepanjang perbaikan dapat dilakukan. Contoh kelemahan yang dirasakan organisasi pada umumnya antara lain lokasi yang jauh dari jangkauan fasilitas umum, sumber daya manusia yang lemah, keuangan yang tidak memadai, dan lain-lain. Salah satu langkah yang dapat dilakukan untuk mengurangi kelemahan adalah kerja sama dengan berbagai pihak. Setiap organisasi mempunyai kekuatan dan kelemahan yang berbeda sehingga keduanya bisa saling menguatkan.

Faktor eksternal meliputi dari Peluang dan ancaman.

\section{Opportunities (Peluang)}

Dalam scanning lingkungan, apa yang dianggap peluang bagi organisasi yang satu belum tentu merupakan peluang bagi organisasi yang lain. Mungkin baginya itu adalah ancaman. Peluang (opportunities) dapat diartikan sebagai kesempatan dan kemungkinan yang tersedia dan dapat dimanfaatkan untuk mendorong proses kinerja pembangunan daerah atau organisasi bersangkutan.

2. Threats (Ancaman)

Ancaman (Threats) dapat pula di artikan sebagai suatu kondisi atau permasalahan yang datang dari luar dan dapat menimbulkan kesulitan, kendala atau tantangan yang cukup serius bagi suatu daerah atau institusi tertentu.

\section{METODE PENELITIAN}

Penelitian ini merupakan penelitian kualitatif deskripstif dengan menggunakan metode studi kasus, dimana penelitian dilakukan secara mendalam dan intensif untuk mengungkapkan bagaimana strategi Pemerintah Kota Padang dalam pengembangan Pantai Muaro Lasak sebagai ikon Kota Padang. Penelitian dilakukan di kawasan Pantai Muaro Lasak Kota Padang, Dinas Parawisata Kota Padang, dan di Dinas Pekerjaan Umum Penataan Ruang Kota Padang. Informan dalam penelitian ini ditentukan secara purposive sampling, yaitu Kasi Pendataan dan Perencanaan dan Kasi Usaha dan Industri Parawisata Dinas Pariwisata dan Kebudayaan Kota Padang, Kasi Perencanaan Tata Ruang Kota PUPR Kota Padang, para wisatawan, pedagang kaki lima dan tukang Parkir di Pantai Muaro Lasak.

Data yang digunakan yaitu data primer dan data sekunder, yang berasal dari wawancara, observasi, dan studi dokumentasi. Data ini di uji keabsahannya dengan teknik triangulasi sumber, yaitu dengan membandingkan hasil pengamatan dengan hasil wawancara dan mewawancarai informan dari berbagai sumber. Data ini kemudian di analisis dengan teknik analisis data kualitatif mulai 
dari reduksi data, data display, hingga kesimpulan verifikasi.

\section{HASIL DAN PEMBAHASAN}

Upaya Pemerintah Kota Padang dalam Pengembangan Pantai Muaro Lasak Sebagai Salah Satu Ikon Parawisata

Dalam upaya pemerintah Kota Padang melalui Dinas Parawisata dan Kebudayaan kota Padang, melakukan upaya dengan beberapa diantaranya yaitu :

1. Menentukan Karakteristik Wisatawan

Menentukan karakteristik wisatawan dalam perencanaan dan pengembangan pariwisata perlu memperhatikan beberapa aspek yaitu salah satunya adalah karakteristik dari wisatawan harus diketahui karakteristik dari wisatawan, dari negara mana mereka datang, usia, hobi, dan pada musim apa mereka melakukan perjalanan.

Dengan dibuatnya pantai Muaro Lasak sebagai salah satu objek wisata diKota Padang saat ini pemerintah Kota Padang harus memperhatikan salah satu aspek dalam perencanaan dan pengembangan pantai Muaro Lasak yaitu salah satunya adalah karakteristik dari wisatawan, karakteristik dari wisatawan dapat membantu pemerintah kota padang dalam pengembangan pantai Muaro Lasak.

Dalam temuan penelitian pemerintah Kota Padang berupaya membuat objek wisata Kota padang untuk ramah oleh semua kalangan baik dari kalangan muda, lanjut usia maupun untuk anak-anak.

\section{Akses Transportasi}

Dinas Parawisata dan Kebudayaan Kota Padang mempunyai program dalam pengadaan penyediaan bus untuk parawisataan yang berkunjung ke Kota Padang khususnya pantai Muaro Lasak pengadaan bus tersebut diharapkan dapat meningkatakan kenyamanan dan dapat meningkatkan pengunjung ke Kota padang, bahkan untuk menggenjot sektor parawisata dinas Parawisata dan kebudayaan Kota Padang bekerja sama dengan kementrian perhubungan untuk membuka beberapa perjalanan internasional di bandara Minang Kabau.

\section{Objek Wisata}

Dalam pengembangan parawisata sebuah objek wisata harus mempunyai 3 hal dasar dalam pengembangannya 3 hal dasar tersebut adalah apa yang dapat dilihat, apa yang dapat yang dapat dilakukan dan apa yang dapat dibeli.

Pengembangan yang dilakukan oleh dinas Parawisata dan Kebudayaan Kota Padang memenuhi semua kriteria tersebut, disana apa yang dapat dilihat yaitu pesona pantai Muaro Lasak yang cukup eksotis, lalu apa yang dapat dilakukan dengan melihat pesonanya indah matahari terbenam membuat Muaro Lasak sebagai salah satu tempat wisata yang baik dikota padang ditambah lagi apa yang dapat dibeli, di Muaro Lasak kita disugihkan oleh kulinerkuliner yang beragam sehingga kita dapat menikmatinya sembari duduk santai dan melihat matahari terbenam.

\section{Penyediaan Fasilitas Pelayanan}

Fasilitas pelayanan menjadi sangat penting untuk pengembangan pantai dalam pengembangan pantai Muaro Lasak selain dalam pengembangan transportasi pemerintah Kota Padang melalui dinas Parawisata dan Kebudayaan Kota Padang ingin memberikan kenyamanan dalam berwisata dengan memberikan beberapa fasilitas pelayanan seperti hotel, restaurant dan bank, dan pos pengamanan.

Pemerintah Kota Padang memang tidak secara lansung membangun fasilitasfasilitas pelayanan tersebut namun dengan dibangunnya infrastuktur untuk wisata dan banyak menggaet parawisatawan sehingga para perusahaan dan warga sekita membangun fasilitas tersebut seperti tempat wisata kuliner dan hotel-hotel yang telah bekoodinasi dengan dinas Parawisata dan kebudayaan Kota padang yang dimana diharapkan dapat membuat tempat wisata yang ramah. 
5. Informasi dan Promosi Tempat wisata

Diperlukan publikasi atau promosi, kapan iklan dipasang, kemana brosur disebarkan sehingga calon wisatawan mengetahui tiap paket wisata dan wisatawan cepat mengambil keputusan pariwisata di wilayahnya dan harus menjalankan kebijakan yang paling menguntungkan bagi daerah dan wilayahnya.

Dalam pengembangan pantai Muaro Lasak informasi dan promosi adalah salah satu hal yang penting untuk meningkatkan para pengunjung yang ingin berwisata di pantai Muaro Lasak, dinas Parawisata dan kebudayaan Kota Padang melakukan penyebaran informasi dan promosi melalui sosial media seperti Facebook dan Instagram, dan promosi sendiri dinas Parawisata melakukan event-event yang menampilkan keindahan budaya serta lomba-lomba untuk menggaet para pengunjung dari berbagai negara.

Hal ini dapat diharapkan dapat membantu tempat - tempat wisata di Kota Padang dikenal bukan hanya dari dalam negri akan tetapi juga dikenal sampai ke luar negri.

\section{Faktor-Faktor Pendukung dan Penghambat Pengembangan pantai Muaro Lasak sebagai salah satu Ikon Parawisata}

1. Faktor Penghambat dalam pengembangan pantai Muaro Lasak Kota Padang

Dalam pengembangan pantai Muaro Lasak bukan tanpa hambatan, dalam temuan peneliti dan hasil wawancara terdapat beberapa faktor yang menjadi hambatan dalam pengembangan pantai Muaro Lasak yang pertama yaitu sebagai berikut :

Dalam pengembangan pantai Muaro Lasak Kota Padang mengalami beberapa kendala, baik itu dari lapangan maupun dari internal pemerintah, akan tetapi kami dari dinas Parawisata dan Kebudayaan Kota Padang cukup berhasil dalam pengembangan pantai Muaro Lasak ini tentunya dengan bantuan dari pemerintah pusat dan masyarakat sekitar yang mendukung dengan adanya pengembangan pantai Muaro Lasak ini.

Pemerintah Kota Padang melalui dinas Parawisata dan Kebudayaan Kota Padang mengalami beberapa kendala dalam pengembangan Pantai Muaro Lasak ini, dari beberapa kendala tersebut faktor internal antara lain adalah :

a) Keterbatasan Dana

Dalam pengembangan Pantai Muaro Lasak keterbatasan dana adalah masalah klasik yang dialami oleh sebuah instansi pemerintah, hal ini pun berlaku pada dinas Parawisata dan Kebudayaan Kota Padang yang mengalami hal serupa, dalam pengembangan pantai dinas Parawisata dan Kebudayaan Kota Padang bekoordinasi dengan sejumlah lembaga lainnya hal ini agar pengembangan pantai tersebut berjalan dengan baik, akan tetapi masih menemukan beberapa kendala dalam pengembangan pantai Muaro Lasak tersebut, salah satunya adalah masalah klasik yaitu tentang dana yang dipergunakan untuk pengembangan pantai Muaro Lasak.

Dapat di ketahui dalam pengembagan pantai ini membutuhkan dana yang cukup besar, dalam pengembangan pantai Padang Dinas Parawisata dan Kebudayaan Kota Padang membaginya menjadi 6 tahap agar perencanaan dan pengembangannya lebih mudah dan efisien, dalam 1 tahap tersebut setidaknya memakan dana 2.3 miliar yang berarti secara keseluruhan kira-kira bisa menghabiskan dana sebesar 25 miliar.

\section{Gambar 1. Arena Sketboard di Pantai Muaro Lasak yang Sempat Tertunda Karena Keterbatasan Anggaran}

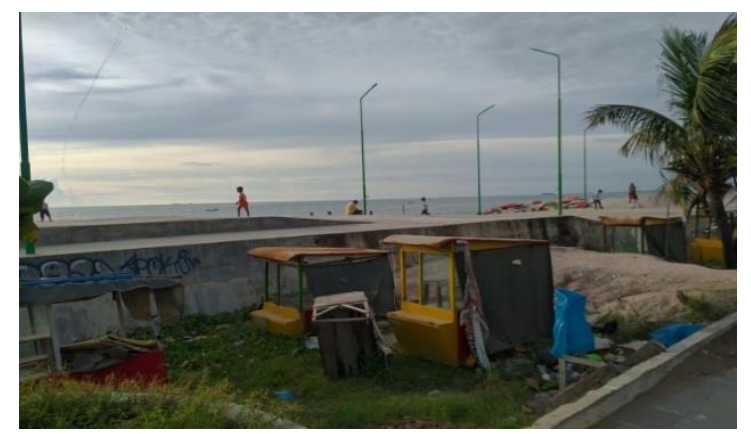


Terbatasnya anggaran untuk pengembangan pantai Muaro Lasak membuat dinas Parawisata dan Kebudayaan kota padang cukup kesulitan dalam pengembangan Pantai Muaro Lasak sehingga ada beberapa infrastruktur yang tertunda, contohnya seperti dalam pengembangan Kios untuk pedagang Pantai Muaro Lasak, memiliki sebuah kios-kios kecil untuk mereka berjualan seperti yang terletak di pantai Purus, akan tetapi hal ini terkendala dalam anggaran yang memakan biaya yang cukup besar, sehingga dikarenakan memakan biaya yang cukup banyak akhirnya para pedagang membuat sendiri kios-kios mereka seadanya.

Namun walaupun dalam pengembanga pantai Muaro Lasak Kota Padang mempunyai masalah berupa masalah anggaran, pemerintah Kota Padang melalui Dinas Parawisata dan Kebudayaan Kota Padang berupaya menimalisir besarnya keluaran anggaran untuk pengembangan Pantai Muaro Lasak dengan cara bekerja sama beberapa instansi atau dengan perusahaan lain.

\section{Gambar 2. Tulisan Taman Muaro Lasak yang Bekerjasama dengan Bank Nagari}

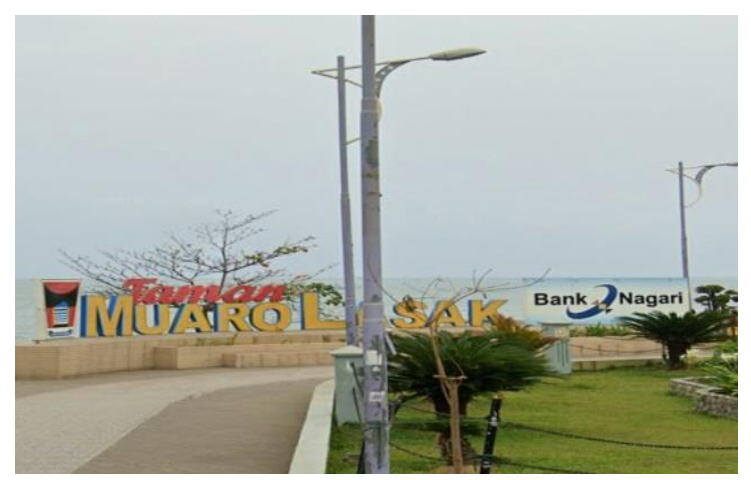

b) Pembebasan Lahan

Dalam pengembangan pantai Muaro Lasak pembebasan lahan adalah salah satu masalah yang harus dihadapi oleh dinas Parawisata dan Kebudayaan Kota Padang hal ini dikarenakan para warga nelayan dikawasan pantai Muaro Lasak sudah bertahun - tahun bermukim di kawasan tersebut sehingga dikarenakan sudah nyaman dengan kondisi disana mereka enggan untuk di relokasi, dalam pengembangan Pantai Muaro Lasak sebagai salah satu ikon wisata adanya penolakan dari beberapa nelayan disekitar, hal ini dikarenakan ditepi pantai tersebut adalah tempat menepinya kapal-kapal nelayan tersebut, akan tetapi Dinas Parawisata dan Kebudayaan Kota Padang mencoba melakukan mediasi dengan para nelayan tersebut untuk pentingnya pengembangan tesebut bagi hajat hidup orang banyak, sehingga mereka pun mau memindahkan kapal-kapal mereka yang saat ini bertempat di bawah jembatan penghubung pantai Muaro Lasak, selain itu para nelayan pantai Muaro Lasak juga diberikan bantuanbantuan untuk kepentingan tangkapan laut mereka.

Selain itu para nelayan Muaro Lasak yang saat ini direlokasi ke tepian sungai akibat adanya pengembangan pantai Muaro Lasak mereka turut bersyukur atas adanya pengembangan tersebut, setelah pembangunan pantai Muaro Lasak sudah baik, dan para nelayan cukup bersyukur adanya pengembangan tersebut, hal ini dikarenakan adanya mata pencarian lain bagi mereka selain melaut ketika para suami pergi melaut para keluarga lainnya berdagang di kawasana pantai Muaro Lasak,hal ini terjadi sebab tempat tersebut saat ini banyak dikunjungi oleh parawisatawan, bahkan ada beberapa nelayan yang berhenti melaut dan membuka dagangan mereka disana.

c) Faktor Alam

Dalam pengembangan pantai Muaro Lasak Kota Padang, faktor alam menjadi salah satu penghambat dalam pengembangan tersebut hal ini dikarenakan besarnya ombak ke tepian pantai secara terus menuerut sehingga membuat tepian pantai mengalami pengikisan, air laut atau ombak yang besar membuat bibir pantai Muaro Lasak mengalami pengikisan atau abrasi sehingga ditakutkan nanti sampai ke fasilitas-fasilitas yang sedang di bangun di pantai Muaro Lasak, apalagi ketika musim hujan datang hal tersebut dapat menambah abrasi ditepian pantai Muaro Lasak 
2. Faktor pendukung pengembangan Pantai Muaro Lasak Kota Padang

Dalam hasil wawancara dan data pendukung lainnya peneliti mendapati berupa faktor - faktor pendukung dari pengmbangan pantai Muaro Lasak Kota Padang yang terbagi dua yaitu faktor internal dan faktor eksternal.

a) Faktor Internal

Dalam faktor internal pendukung pengembangan pantai Muaro Lasak Kota Padang peneliti berdasarkan hasil wawancara, dalam pengembangan pantai Muaro Lasak Kota Padang hal yang memotvasi Dinas Parawisata dan Kebudayaan Kota Padang untuk melakukan pengembangan tersebut adalah visi misi dari dinas Parawisata dan Kebudayaan Kota Padang sendiri, visi dinas Parawisata dan Kebudayaan Kota Padang sendiri yaitu menjadi kan Kota Padang sebagai kota pesisir yang nyaman dikunjungi oleh parawisatwawan baik itu wisatawan lokal maupun wisatawan mancanegara.

Selain hal tersebut dinas Parawisata dan Kebudayaan Kota Padang ingin lebih menngkatkan lagi pendapatan PAD sektor parawisata Kota Padang.

Tabel 1. Data PAD Sektor Parawisata dan PAD Kota Padang 2016-2018

\begin{tabular}{|c|c|c|c|}
\hline $\begin{array}{l}\text { Tahun } \\
\text { Anggaran }\end{array}$ & $\begin{array}{l}\text { PAD Seltor Pararisizata } \\
\text { (Rp) }\end{array}$ & $\begin{array}{l}\text { PAD Kota Padang } \\
(\mathbb{R P})\end{array}$ & Persentase $(\%)$ \\
\hline 2016 & Rp.56.678.716.300 & Rp. 391.925.662.646 & 6.91 \\
\hline 2017 & Rp. 73.409 .705 .231 & Rp. 456.2959 .916 .658 & 6.21 \\
\hline 2018 & Ro. 87.449.011.984 & Rp. 487.655.433.745 & 5.57 \\
\hline Jumlah & Rp.217,537,433.515 & Rp, 1,335:277,013,049 & 6.13 \\
\hline
\end{tabular}

Sumber : Pendapatan Daerah Kota Padang

b) Faktor Eksternal

Dalam faktor eksternal pendukung pengembangan pantai Muaro Lasak Kota Padang berdasarkan hasil wawancara peneliti, dinas Parawisata dan Kebudayaan Kota Padang memiliki tujuan dalam pengembangan Pantai Muaro Lasak ini, yaitu salah satunya agar bisa membuka lapangan pekerjaan baru seperti membuka bisnis usaha kuliner, selain itu pengembangan pantai Muaro Lasak Kota Padang ini bisa membuka lapangan kejra dari kita lihat banyak masyarakat di sekitaran pantai Muaro Lasak memliki banyak opsi dalam memperoleh pendapatan, dari sebelumnnya mereka hanya melaut, sekarang kebanyakan ibu2 rumah tangga disana mulai berjualan disekitaran pantai tersebut, hal ini dikarenakan adanya pengembangan sehingga menarik para wisatawan yang berkunjung ke daerah pantai, lagi pengembangan dari daerah wisata pantai Muaro Lasak ini bertujuan agar pemberataan pembangaunan, bisa kita lihat semenjak dilakukannya pengembangan di pantai Muaro Lasak ini pembangunan disana mulai terlihat seperti pembangunan - pembangunan hotel dan lain sebagainya, dapat mengetahui bawasanya pemerintah Kota Padang melalui dinas Parawisata dan kebudayaan Kota Padang melakukan pengembangan pantai Muaro Lasak agar masyarakat disekitaran pantai dapat membantu perekonomian keluarga mereka seperti berjualan berbagai aneka kuliner, hal ini pun disampaikan oleh salah satu pedagang pantai Muaro Lasak yang bernama buk Yurliani yang mengatakan bahwa :

“...saya dipantai Muaro Lasak sudah berjualan sekitar 5 tahunan ini sebelumnya keluarga bergantung pada hasil suami yang berprofesi sebgai nelayan tradisional di pantai Muaro Lasak, akan tetapi semenjak pemerintah Kota Padang melakukan pembangunanpembangunan di kawasan pantai ini para masyarakat dari daerah maupun luar daerah mulai berdatangan di kawasan ini, lalu saya pun membuka usaha kuliner di pantai Muaro Lasak agar dapat membantu pereknomian keluarga"

Dapat diketahui bawasanya para pedagang dipantai Muaro Lasak kota Padang menyambut baik pengembangan 
pantai ini dan diantara merekka banyak yang membangun kios - kios disekitaran pantai untuk berjualan, hal ini dilakukan agar dapat membantu perekonomian keluarga mereka.

\section{PENUTUP}

Pelaksanaan pengemangan pantai Muaro Lasak saat ini telah dilakukan dan terleksana secara cukup baik, yaitu dengan melalui tahapan-tahapan yang dilaksanakan oleh Dinas Parawisata dan Kebudayaan Kota Padang, dalam pelaksanaannya pengembangan pantai padang melalui 6 tahap, tujuan dari pembagian tahapantahapan tersebut agar memudahkan Dinas Parawisata dan Kebudayaan Kota Padang membangun desain dan memudahkan dalam hal penganggaran.

Dalam pengembangannya dinas Parawisata dan Kebudayaan Kota Padang dibantu oleh beberapa perusahaanperusahaan untuk membantu pengembangan pantai tersebut hal ini guna untuk menekan anggaran yang keluar dari pusat, dalam tujuan dari pengembangan kawasan pantai Muaro Lasak ini tidak lain untuk membantuk para masyarakat disekitar pantai agar dapat membantu perekonomian keluarga mereka dikarenakan setelah pengubahan pantai Muaro Lasak sebagai salah satu ikon parawisata banyak yang berkunjung ke kawasan tersebut baik masyarakat dari dalam, luar daerah bahkan sampai mancanegara .

Dinas Parawisata dan Kebudayaan sendiri tujuan dari pengembangan ini agar menambah PAD dari Kota Padang serta menjalankan salah satu Undang-Undang Nomor 10 tahun 2009 Tentang Kepariwisatan, dan juga menjalankan dari tugas dan fungsi dari dinas Parawisata dan Kebudayaan itu sendiri berdasarkan Peraturan Walikota Nomor 83 Tahun 2016 tentang Kedudukan, Susunan Organisasi, Tugas Fungsi dan Tata kerja Dinas Parawisata dan Kebudayaan.

Faktor yang mempengaruhi dalam pengembangan Pantai Muaro Lasak Kota
Padang, terdiri dari dua faktor yaitu faktor internal dan faktor eksternal. Pertama faktor internal lambatnya pencairan dana dari pemerintah pusat berdampak pada pengembangan pantai Muaro Lasak dikarenakan beberapa dari pembangunan infrastruktur menjadi terhambat pengerjaannya, faktor eksternal adanya premanisme dari pantai Muaro Lasak tersebut dikarenakan hilangnya mata pencarian mereka sebelumnya dan juga faktor dari alam berdampak pada adanya abrasi disekitar pantai Muaro Lasak berdampak tertundanya pengembangan pantai tesebut dan menunggu pembangunan batu grip atau pemecah ombak.

\section{DAFTAR KEPUSTAKAAN}

Ali Kabul Mahi. 2016. Pengembangan Wilayah Teori\&Aplikasi. Jakarta : Kencana.

I Gusti Bagus arjana (2015). Geografi Parawisata dan Ekonomi Kreatif. Depok : Pt. Raja Grafindo Persada.

I Ketut Suwena dkk. (2017). Pengetahuan Dasar Ilmu Parawisata. Denpasar : Pustaka Lasaran.

Novi Yanti.2018 . Analisis Pengembangan Sektor Parawisata di Kota Padang. Program Studi Manajemen Fakultas Ekonomi. Universitas Ekasakti.

Pinata, I Gde dkk. (2009). Pengantar Ilmu Parawisat.Yogyakarta : $\mathrm{Cv}$ Andi Offset.

Salusu. (2015). Pengambilan Keutusan Strategik Untuk Organisasi Publik dan Organisasi Non Profit. Jakarta : Grasindo. 